\title{
Coumarins from the aerial parts of Artemisia iwayomogi Kitamura
}

\author{
Trong Nguyen Nguyen ${ }^{1} \cdot$ Hyeong-Ju Jeon $^{2}$ (D) Hyoung-Geun Kim ${ }^{1}$ (D) \\ Yeong-Geun Lee ${ }^{1} \cdot$ Seung Soo $\mathrm{Lee}^{3} \cdot$ Myun Ho Bang ${ }^{3} \cdot$ Nam-In Baek ${ }^{1}$
}

Received: 17 September 2020 / Accepted: 14 October 2020 / Published Online: 31 December 2020

(C) The Korean Society for Applied Biological Chemistry 2020

\begin{abstract}
Artemisia iwayomogi (Compositae), a perennial mugwort, is native to Korea and widely distributed in Japan, Russia, and China. A. iwayomogi and A. capillaris are similar in morphology and pharmacological activity and have been used for the same medicinal purposes in Korea. While various ingredients such as coumarins and flavonoids and their activity studies have been reported for $A$. capillaris, few studies have been conducted on the pharmacologically active components of $A$. iwayomogi. In Korea, $A$. capillaris is not economical because only young leaves are used as a medicinal material. Because of this, A. iwayomogi is frequently used in Korea, indicating the need to study its pharmacologically active components. Therefore, a phytochemical study was initiated to isolate active compounds from the aerial parts of A. iwayomogi. Finally, four coumarins, umbelliferone (1), esculetin (2), grevillone (3), and scoparone (4) were isolated for the first time from the aerial parts of A. iwayomogi in this study.
\end{abstract}

Keywords Artemisia iwayomogi $\cdot$ Coumarin $\cdot$ Nuclear magnetic resonance $\cdot$ Preparative MPLC

Nam-In Baek ( $\bowtie)$

E-mail: nibaek@khu.ac.kr

${ }^{1}$ Graduate School of Biotechnology and Department of Oriental Medicine Biotechnology, Kyung Hee University, Yongin 17104, Republic of Korea

${ }^{2}$ Department of Food and Nutrition, Jangan University, HwaSeong, Gyeonggi 18331, Republic of Korea

${ }^{3}$ Skin Biotechnology Center, Kyung Hee University, Suwon 16229, Republic of Korea

This is an Open Access article distributed under the terms of the Creative Commons Attribution Non-Commercial License (http://creativecommons. org/licenses/by-nc/3.0/) which permits unrestricted non-commercial use, distribution, and reproduction in any medium, provided the original work is properly cited.

\section{Introduction}

Artemisia iwayomogi Kitamura (Compositae) is a perennial aromatic herb with yellow flowers. It is distributed in Korea, Japan, Sakhalin, the Kuril Islands in Russia, and Manchuria in China [1-3]. More than 30 species in this genus are found in Korea [4]. Among them, A. iwayomogi and A. capillaris are similar in terms of external appearance and pharmacological use. The aerial parts of A. iwayomogi and A. capillaris have been used in traditional medicine with the Korean name "Injin" [4]. A. capillaris is a common perennial herb and has been used for treatment of hepatitis, carbuncle, cholecystitis, and jaundice [2,3]. The major active components of $A$. capillaris are coumarins and flavonoids [5]. Though many phytochemical and pharmacological studies on $A$. capillaris have been carried out, only a few studies have been conducted on the pharmacologically active components of $A$. iwayomogi. Therefore, this study was initiated to isolate active compounds from the aerial parts of $A$. iwayomogi.

Coumarins, are 1,2-benzopyrones or 2H-1-benzopyran-2-ones, that consist of benzene rings joined by a $\alpha$-pyrone ring and conjugated system with rich electron and good charge-transport properties [68]. They were synthesized via the phenylpropanoid pathway and have diverse structural modifications [9]. Coumarin is an oxygen heterocycle that occurs either in free or combined form with glucose. They have received attention for their diverse bioactivities. Coumarins were reported to act as competitive inhibitors of vitamin $\mathrm{K}$ but also show selective cytotoxicity on tumor cells [10]. They also regulate the immune response, cell growth, and differentiation [11]. In addition, some of its derivatives have been used as aroma agent for enhancing sense of tobaccos, alcoholic drinks, and perfumes [12,13]. Hence, the EtOAc fraction of A. iwayomogi and isolated coumarins may be valuable for use as additives in food, cosmetic, and drug industries. 
The EtOAc fraction from the aerial parts of Artemisia iwayomogi $(290 \mathrm{~g})$

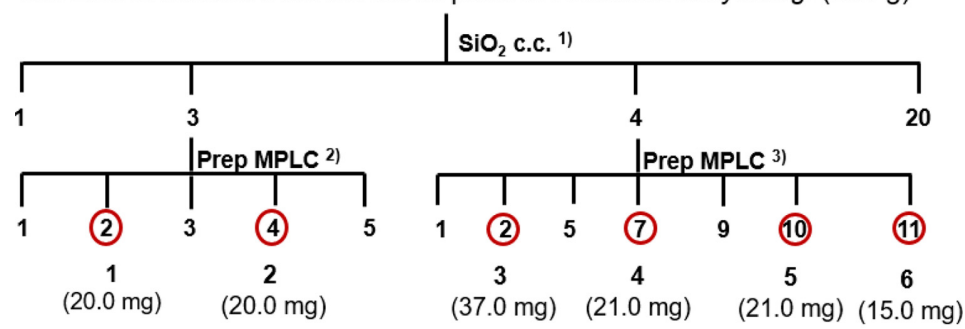

1) $\varnothing 11 \times 16 \mathrm{~cm} / \mathrm{CHCl}_{3}-\mathrm{MeOH}-\mathrm{H}_{2} \mathrm{O}=30: 3: 1$

2) Preparative MPLC/ $\mathrm{C} 18, \varnothing 100 \times 250 \mathrm{~mm} / \mathrm{MeOH}-\mathrm{H}_{2} \mathrm{O}=60: 40$

(r.t: 1, 8 mins; 2, 42 mins)

3) Preparative MPLC/ C18, $\varnothing 100 \times 250 \mathrm{~mm} / \mathrm{MeOH}-\mathrm{H}_{2} \mathrm{O}=60: 40$

(r.t: 3, 9 mins; 4, 50 mins; 5, 84 mins; 6, 105 mins)

Fig. 1 Isolation procedure of coumarins from the aerial parts of Artemisia iwayomogi

\section{Materials and Methods}

\section{Plant materials}

The aerial parts of Artemisia iwayomogi were provided by RDA, Eumseong, Korea, in 2019 and identified by Dr. Jin Tae Jung, RDA, Eumseong, Korea. A voucher specimen has been stored in Natural Products Chemistry Laboratory, Kyung Hee University, Yongin, Korea.

\section{General experimental procedures}

The materials and equipment we used for the isolation and structure determination of constituents are described in a previous study [14].

Isolation of the coumarins from the aerial parts of $\boldsymbol{A}$. iwayomogi The dried aerials parts of $A$. iwayomogi $(4.5 \mathrm{~kg}$ ) were soaked in $80 \%$ aqueous $\mathrm{MeOH}(4.5 \mathrm{~L} \times 3)$ at room temperature for $24 \mathrm{~h}$. After filtration, the extract was concentrated to afford $1.07 \mathrm{~kg}$ of residue. The obtained concentrate was suspended in $\mathrm{H}_{2} \mathrm{O}(4.2 \mathrm{~L})$ and sequentially extracted with EtOAc $(4 \mathrm{~L} \times 3)$ and $n$-BuOH (3.6 $\mathrm{L} \times 3$ ), which were concentrated to obtain EtOAc (AIE, $290 \mathrm{~g}$ ), $n$-BuOH (AIB, $220 \mathrm{~g}$ ), and $\mathrm{H}_{2} \mathrm{O}$ (AIW, $560 \mathrm{~g}$ ) fractions, respectively. The isolation procedures of compounds 1-6 from the aerial parts of A. iwayomogi are presented in Fig. 1.

Umbelliferone (1) Colorless needles; positive FAB-MS m/z 163 $[\mathrm{M}+\mathrm{H}]^{+}$; IR $\left(\mathrm{KBr}, v, \mathrm{~cm}^{-1}\right) 3077(-\mathrm{OH}), 1677(\gamma$-lactone $\mathrm{C}=\mathrm{O})$, 1562 and 1507 (aromatic benzene ring); ${ }^{1} \mathrm{H}-\mathrm{NMR}\left(600 \mathrm{MHz}, \delta_{\mathrm{H}}\right)$ $(\mathrm{PMR})$ and ${ }^{13} \mathrm{C}-\mathrm{NMR}\left(150 \mathrm{MHz}, \delta_{\mathrm{C}}\right)(\mathrm{CMR})\left(\mathrm{C}_{5} \mathrm{D}_{5} \mathrm{~N}\right)$ see Tables 1 and 2.

Esculetin (2) Colorless needles; positive FAB-MS m/z 179 $[\mathrm{M}+\mathrm{H}]^{+}$; IR $\left(\mathrm{KBr}, v, \mathrm{~cm}^{-1}\right) 3413(-\mathrm{OH}), 1656(\gamma$-lactone $\mathrm{C}=\mathrm{O})$, 1567 (aromatic benzene ring); $\mathrm{PMR}$ and $\mathrm{CMR}\left(\mathrm{CD}_{3} \mathrm{OD}\right)$ see Tables 1 and 2.

Grevillone (3) Colorless needles; positive FAB-MS m/z 163 $[\mathrm{M}+\mathrm{H}]^{+}$; IR $\left(\mathrm{KBr}, v, \mathrm{~cm}^{-1}\right) 3539(-\mathrm{OH}), 1654$ (ã-lactone $\left.\mathrm{C}=\mathrm{O}\right)$,

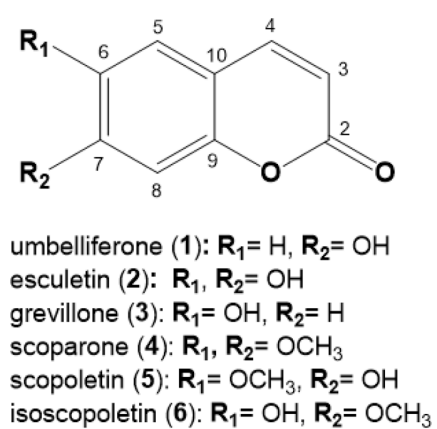

Fig. 2 Chemical structures of coumarins from the aerial parts of Artemisia iwayomogi

1574 and 1514 (aromatic benzene ring); PMR and CMR $\left(\mathrm{C}_{5} \mathrm{D}_{5} \mathrm{~N}\right)$ see Tables 1 and 2 .

Scoparone (4) Colorless needles; positive FAB-MS m/z 207 $[\mathrm{M}+\mathrm{H}]^{+}$; IR $\left(\mathrm{KBr}, \quad v, \mathrm{~cm}^{-1}\right) 1648 \quad(\gamma$-lactone $\mathrm{C}=\mathrm{O}), 1537$ (aromatic); PMR and $\mathrm{CMR}\left(\mathrm{CDCl}_{3}\right)$ see Tables 1 and 2.

Scopoletin (5) Yellow needles; positive FAB-MS m/z 193 $[\mathrm{M}+\mathrm{H}]^{+}$; IR $\left(\mathrm{KBr}, v, \mathrm{~cm}^{-1}\right) 3373(-\mathrm{OH}), 1648(\gamma$-lactone $\mathrm{C}=\mathrm{O})$, 1542 and 1510 (aromatic benzene ring); PMR and CMR $\left(\mathrm{C}_{5} \mathrm{D}_{5} \mathrm{~N}\right)$ see Tables 1 and 2 .

Isoscopoletin (6) Colorless needles; positive FAB-MS m/z 193 $[\mathrm{M}+\mathrm{H}]^{+}$; IR $\left(\mathrm{KBr}, v, \mathrm{~cm}^{-1}\right) 3285(-\mathrm{OH}), 1627(\gamma$-lactone $\mathrm{C}=\mathrm{O})$, 1560 and 1508 (aromatic benzene ring); PMR and $\mathrm{CMR}\left(\mathrm{C}_{5} \mathrm{D}_{5} \mathrm{~N}\right)$ see Tables 1 and 2.

\section{Results and Discussion}

The aerial parts of $A$. iwayomogi were extracted in aqueous $\mathrm{MeOH}$, and the obtained extracts were partitioned using EtOAc, $n$ - $\mathrm{BuOH}$, and water. Repeated silica gel column chromatography and prep MPLC of AIE fraction yielded six coumarins.

Compound 1, a colorless needle, was showed a pink color on 
Table $1{ }^{13} \mathrm{C}-\mathrm{NMR}$ data of coumarins from the aerials parts of Artemisia iwayomogi $\left(150 \mathrm{MHz}, \delta_{\mathrm{C}}\right)$

\begin{tabular}{|c|c|c|c|c|c|c|}
\hline No of $\mathrm{C}$ & $1 *$ & 2 & 3 & 4 & 5 & 6 \\
\hline 2 & 162.54 & 162.16 & 170.23 & 161.64 & 161.93 & 162.48 \\
\hline 3 & 114.45 & 112.37 & 117.05 & 114.55 & 113.97 & 114.86 \\
\hline 4 & 144.36 & 145.17 & 146.67 & 144.24 & 143.85 & 145.26 \\
\hline 5 & 129.87 & 112.04 & 115.86 & 108.46 & 112.57 & 112.13 \\
\hline 6 & 111.63 & 142.93 & 150.71 & 147.78 & 148.68 & 147.19 \\
\hline 7 & 161.37 & 148.85 & 127.53 & 151.92 & 145.24 & 156.69 \\
\hline 8 & 102.49 & 103.15 & 117.16 & 100.61 & 100.05 & 105.37 \\
\hline 9 & 156.92 & 151.16 & 147.94 & 150.82 & 152.64 & 154.83 \\
\hline 10 & 111.43 & 111.48 & 127.65 & 113.33 & 112.73 & 111.39 \\
\hline 6-OMe & - & - & - & 56.74 & 56.59 & - \\
\hline 7-OMe & - & - & - & 56.74 & - & 57.26 \\
\hline
\end{tabular}

*Compounds $\mathbf{1}, \mathbf{3}, \mathbf{5}$, and $\mathbf{6}$ in $\mathrm{C}_{5} \mathrm{D}_{5} \mathrm{~N}$; compounds $\mathbf{2}$ and $\mathbf{4}$ in $\mathrm{CD}_{3} \mathrm{OD}$

Table $2{ }^{1} \mathrm{H}-\mathrm{NMR}$ data of coumarins from the aerials parts of Artemisia iwayomogi $\left(600 \mathrm{MHz}, \delta_{\mathrm{H}}\right.$, coupling pattern, $J$ in $\left.\mathrm{Hz}\right)$

\begin{tabular}{|c|c|c|c|c|c|c|}
\hline No of $\mathrm{H}$ & $1^{*}$ & 2 & 3 & 4 & 5 & 6 \\
\hline 3 & $7.69, \mathrm{~d}, 9.0$ & $7.92, \mathrm{~d}, 9.0$ & $8.19, \mathrm{~d}, 9.0$ & $7.64, \mathrm{~d}, 9.0$ & $7.69, \mathrm{~d}, 9.0$ & $7.7, d, 9.0$ \\
\hline 4 & $6.3, \mathrm{~d}, 9.0$ & $6.13, \mathrm{~d}, 9.0$ & $6.81, \mathrm{~d}, 9.0$ & $6.29, \mathrm{~d}, 9.0$ & $6.39, \mathrm{~d}, 9.0$ & $6.31, \mathrm{~d}, 9.0$ \\
\hline 5 & $7.43, \mathrm{~d}, 9.0$ & $6.69, \mathrm{~s}$ & $7.66, \mathrm{~s}$ & $6.87, \mathrm{~s}$ & $7.25, \mathrm{~s}$ & $7.14, \mathrm{~s}$ \\
\hline 6 & $7.08, \mathrm{dd}, 9.0,2.0$ & - & - & - & - & - \\
\hline 7 & - & - & $7.25, \mathrm{dd}, 9.0,2.0$ & - & - & - \\
\hline 8 & $7.05, \mathrm{~d}, 2.0$ & $6.71, \mathrm{~s}$ & $7.21, \mathrm{~d}, 9.0$ & $6.85, \mathrm{~s}$ & $6.69, \mathrm{~s}$ & $7.07, \mathrm{~s}$ \\
\hline 6-OMe & - & - & - & $3.93, \mathrm{~s}$ & $3.91, \mathrm{~s}$ & - \\
\hline 7-OMe & - & - & - & $3.95, \mathrm{~s}$ & - & $3.80, \mathrm{~s}$ \\
\hline
\end{tabular}

*Compounds $\mathbf{1}, \mathbf{3}, \mathbf{5}$, and $\mathbf{6}$ in $\mathrm{C}_{5} \mathrm{D}_{5} \mathrm{~N}$; compounds $\mathbf{2}$ and $\mathbf{4}$ in $\mathrm{CD}_{3} \mathrm{OD}$

TLC by $10 \%$ sulfuric acid spraying and alcohol lamp heating. It showed IR absorbance bands $\left(\mathrm{cm}^{-1}\right)$ due to hydroxyl (3077), conjugated ketone (1677), and aromatic (1562 and 1507) groups. The molecular weight (MW) was determined to be 162 Da based on a detected molecular ion peak $m / z 163[\mathrm{M}+\mathrm{H}]^{+}$in the positive FAB-MS spectrum. PMR spectrum $\left(\mathrm{C}_{5} \mathrm{D}_{5} \mathrm{~N}\right)$ exhibited the signals of three olefin methines $\delta_{\mathrm{H}} 7.43(1 \mathrm{H}, \mathrm{d}, J=9.0 \mathrm{~Hz}, \mathrm{H}-5), \delta_{\mathrm{H}} 7.08$ $(1 \mathrm{H}, \mathrm{dd}, J=9.0,2.0 \mathrm{~Hz}, \mathrm{H} 6), \delta_{\mathrm{H}} 7.05(1 \mathrm{H}, \mathrm{d}, J=2.0 \mathrm{~Hz}, \mathrm{H} 8)$ due to a 1,2,4-trisubstituted benzene ring. Moreover, the signals of two olefin methines $\delta_{\mathrm{H}} 7.69(1 \mathrm{H}, \mathrm{d}, J=9.0 \mathrm{~Hz}, \mathrm{H} 3)$ and $\delta_{\mathrm{H}} 6.30(1 \mathrm{H}$, d, $J=9.0 \mathrm{~Hz}, \mathrm{H} 4)$ were observed with vicinal-coupling. CMR $\left(\mathrm{C}_{5} \mathrm{D}_{5} \mathrm{~N}\right)$ spectrum showed 9 carbon signals. In a low magnetic field, the carbon signals of one ester $\left(\delta_{\mathrm{C}} 162.54, \mathrm{C} 2\right)$, two oxygenated olefinic quaternary carbons $\left(\delta_{\mathrm{C}} 156.92, \mathrm{C} 9 ; \delta_{\mathrm{C}} 161.37\right.$, C7), and five olefinic methine carbons $\left(\delta_{\mathrm{C}} 144.36, \mathrm{C} 4 ; \delta_{\mathrm{C}} 129.87\right.$, $\left.\mathrm{C} 5 ; \delta_{\mathrm{C}} 114.45, \mathrm{C} 3 ; \delta_{\mathrm{C}} 111.63, \mathrm{C} 6 ; \delta_{\mathrm{C}} 102.49, \mathrm{C} 8\right)$ were observed. The above described PMR and CMR signals suggested compound 1 to be a coumarin with one hydroxy group. The HMBC spectrum showed the cross-peaks the oxygenated aromatic quaternary carbon signal $\left(\delta_{\mathrm{C}} 161.37, \mathrm{C} 7\right)$ with three aromatic methine proton signals $\delta_{\mathrm{H}} 7.43(\mathrm{H} 5), \delta_{\mathrm{H}} 7.08(\mathrm{H} 6)$, and $\delta_{\mathrm{H}} 7.05(\mathrm{H} 8)$, respectively, which confirmed the hydroxy group at $\mathrm{C} 7$. Therefore, compound 1 was identified as a 7-hydroxychromen-2-one, umbelliferone.
The chemical shifts of PMR and CMR were confirmed by comparison with literature data [15].

Compound 2, a colorless needle, was showed a pink color on TLC by $10 \%$ sulfuric acid spraying and alcohol lamp heating. It showed IR absorbance bands $\left(\mathrm{cm}^{-1}\right)$ due to hydroxyl (3413), conjugated ketone (1656), and aromatic (1567) groups. The MW was determined to be $178 \mathrm{Da}$, which was $16 \mathrm{Da}$ larger than that of compound $\mathbf{1}$, based on a detected molecular ion peak $\mathrm{m} / \mathrm{z} 179$ $[\mathrm{M}+\mathrm{H}]^{+}$in the positive FAB-MS spectrum, indicating an additional hydroxy group in compound 2. PMR and CMR $\left(\mathrm{CD}_{3} \mathrm{OD}\right)$ spectra of compound $\mathbf{2}$ were very similar to those of compound $\mathbf{1}$, with the exception of the presence of one additional hydroxy group. An olefinic carbon (C6), which was detected at $\delta_{\mathrm{C}}$ 111.66 in compound 1 , was detected at a lower magnetic field, $\delta_{\mathrm{C}}$ 142.93, in compound 2. Therefore, compound 2 was a 6,7dihydroxychromen-2-one, esculetin, a hydroxylated coumarin of umbelliferone.

Compound 3, a colorless needle, was showed a pink color on TLC by $10 \%$ sulfuric acid spraying and alcohol lamp heating to. It showed IR absorbance bands $\left(\mathrm{cm}^{-1}\right)$ due to hydroxyl (3539), conjugated ketone (1654), and aromatic (1574 and 1514) groups. The MW was determined to be 162 based on a detected molecular ion peak $m / z 163[\mathrm{M}+\mathrm{H}]^{+}$in the positive FAB-MS spectrum. 
PMR and CMR $\left(\mathrm{C}_{5} \mathrm{D}_{5} \mathrm{~N}\right)$ spectra of compound 3 were nearly identical to those of compound $\mathbf{1}$ but showed a different hydroxyl group position. The HMBC spectrum showed correlation of the oxygenated olefinic quaternary carbon signal $\delta_{\mathrm{C}} 111.63$ (C6) with three olefinic methine proton signals at $\delta_{\mathrm{H}} 7.66(\mathrm{H} 5), \delta_{\mathrm{H}} 7.25$ $(\mathrm{H} 7)$, and $\delta_{\mathrm{H}} 7.21(\mathrm{H} 8)$, which confirmed the hydroxy group at C6. Therefore, compound $\mathbf{3}$ was identified to be a 7hydroxychromen-2-one, grevillone.

Compound 4, a colorless needle, was showed a pink color on TLC by $10 \%$ sulfuric acid spraying and alcohol lamp heating. It showed IR absorbance bands $\left(\mathrm{cm}^{-1}\right)$ due to conjugated ketone (1648) and aromatic (1537) groups. The MW was determined to be $206 \mathrm{Da}$ based on a detected molecular ion peak $\mathrm{m} / \mathrm{z} 207$ $[\mathrm{M}+\mathrm{H}]^{+}$in the positive FAB-MS spectrum, which was $28 \mathrm{Da}$ larger than compound 2, suggesting transformation of two hydroxy groups to two methoxy groups. The PMR and CMR $\left(\mathrm{CDCl}_{3}\right)$ spectra exhibited two methoxy groups at $\delta_{\mathrm{H}} 3.93$ (6OMe), $\delta_{\mathrm{H}} 3.95(7 \mathrm{OMe})$, and $\delta_{\mathrm{C}} 56.74$ (6OMe, 7OMe). In the HMBC spectrum, the signals of two methoxy protons $\delta_{\mathrm{H}} 3.93$ $(6 \mathrm{OMe})$ and $\delta_{\mathrm{H}} 3.95(7 \mathrm{OMe})$ showed cross peaks with two oxygenated olefinic quaternary carbon signals at $\delta_{\mathrm{C}} 151.92$ (C7) and $\delta_{\mathrm{C}} 147.78$ (C6), respectively. Therefore, compound 4 was identified as a 6,7-dimethoxychromen-2-one, scoparone.

Compound 5, a colorless needle, was showed a pink color on TLC by $10 \%$ sulfuric acid spraying and alcohol lamp heating. It showed IR absorbance bands $\left(\mathrm{cm}^{-1}\right)$ due to hydroxyl (3373), conjugated ketone (1648), and aromatic (1542 and 1510) groups. The MW was determined to be 192 Da based on a detected molecular ion peak $m / z 193[\mathrm{M}+\mathrm{H}]^{+}$in the positive FAB-MS spectrum, which was 14 Da larger than compound 2, $178 \mathrm{Da}$, indicating one hydroxy group was transformed to a methoxy group. The PMR and CMR $\left(\mathrm{C}_{5} \mathrm{D}_{5} \mathrm{~N}\right)$ spectra were almost same as those of compound $\mathbf{5}$ with the exception of one additional signal due to a methoxy group $\delta_{\mathrm{H}} 3.91(6 \mathrm{OMe})$ and $\delta_{\mathrm{C}} 56.59(6 \mathrm{OMe})$. Therefore, compound 5 was identified to be a 7-hydroxy-6methoxychromen-2-one, scopoletin.

Compound 6, a colorless needle, was showed a pink color on TLC by $10 \%$ sulfuric acid spraying and alcohol lamp heating. It showed absorbance bands $\left(\mathrm{cm}^{-1}\right)$ due to hydroxyl (3285), conjugated ketone (1627), and aromatic (1560 and 1508) groups. The MW was determined to be 192 Da based on a detected molecular ion peak $m / z 193[\mathrm{M}+\mathrm{H}]^{+}$in the positive FAB-MS spectrum. The PMR and CMR $\left(\mathrm{C}_{5} \mathrm{D}_{5} \mathrm{~N}\right)$ spectra were similar to those of compound $\mathbf{5}$ with the exception one methoxy and one hydroxy group position. The position of the methoxy group was determined to be $\mathrm{C} 7$ from the cross peak between the methoxy proton signal $\delta_{\mathrm{H}} 3.80(7 \mathrm{OMe})$ and the oxygenated olefinic methine carbon signal $\delta_{\mathrm{C}} 156.69$ (C7). Finally, compound 6 was identified as a 6-hydroxy-7-methoxychromen-2-one, isoscopoletin.

In conclusion, this study was initiated to search for active compounds from the aerial parts of A. iwayomogi. Six coumarins were isolated through repeated column chromatography using
$\mathrm{SiO}_{2}$ resins and prep-MPLC and identified on the basis of spectroscopic data of NMR, IR, UV, and MS. Especially, four coumarins, umbelliferone (1), esculetin (2), grevillone (3), and scoparone (4) were isolated for the first time from the aerial parts of $A$. iwayomogi in this study. These results indicate that the aerial parts of A. iwayomogi could be used as potential pharmacological agents.

Acknowledgments This work was supported by the "Cooperative Research Program for Agriculture Science \& Technology Development" (Project no. PJ01420403), Rural Development Administration, Republic of Korea.

\section{References}

1. William TC, Jianping Y, Aamir Z, David MR, Ilya R, Zhijun Liu, Zhong QW, Phillip JB, Luke H, Michael L (2008) Botanicals and the metabolic syndrome. Am J Clin Nutr 87: 481s-487s

2. Kim J (1989) Illustrated natural drugs encyclopedia. Namsadang Publishers, Seoul

3. Park J (1999) Korean folk medicine. Busan National University Publisher, Busan

4. Seo KS, Jeong HJ, Yun KW (2010) Antimicrobial activity and chemical components of two plants, Artemisia capillaris and Artemisia iwayomogi, used as Korean herbal Injin. J Ecol Field Biol 33: 141-147

5. Schmidt BM, Ribnicky DM, Lipsky PE, Raskin I (2007) Revisiting the ancient concept of botanical therapeutics. Nat Chem Biol 3: 360-366

6. Ojala T (2001) Biological screening of plant coumarins. Dissertation, University of Helsinki, Helsinki

7. Lacy A, O'Kennedy R (2004) Studies on coumarins and coumarinrelated compounds to determine their therapeutic role in the treatment of cancer. Curr Pharm Des 10: 3797-3811

8. Matos MJ, Santana L, Uriarte E, Abreu OA, Molina E, Yordi EG (2015) Phytochemicals Isolation, Characterisation and Role in Human Health. 5:113-140 doi:10.5772/58648

9. Harbone JB (1999) Classes and functions of secondary products from plants. In Walton NJ, Brown DE (eds) Chemicals from plants. Imperial College press, London, pp 125

10. Rohini K, Srikumar PS (2014) Therapeutic role of coumarins and coumarin-related compounds. J Thermodyn Catal. 5:2 doi:10.4172/ 21577544.1000130

11. Vianna DR, Hamerski L, Figueiro F, Bernadi A, Visentin LC, Pires ENS, Teixeira HF, CG Salbego, Eifler VL, Battastini AMO, Poser GL, Pinto AC (2012) Selective cytotoxicity and apoptosis induction in glioma cell lines by 5-oxygenated-6,7-methylenedioxycoumarins from Pterocaulon species. Eur J Med Chem 57: 268-274

12. Fais A, Corda M, Era B, Fadda MB, Matos JM, Quezada E, Santana L, Picciau C, Podda G, Delogu G (2009) Tyrosinase inhibitor activity of coumarin-resveratrol hybrids. Molecules 14(7): 2514-2520

13. Matos MJ, Rodriguez SV, Santana L, Uriarte E, Edfuf CF, Santos Y, Crego AM (2013) Synthesis and structure activity relationships of novel amino/nitro substituted 3-arylcomarins as antibacterial agents. Molecules 18(2): 1394-1404

14. Kim HG, Oh HJ, Ko JH, Song HS, Lee YG, Kang SC, Lee DY, Baek NI (2019) Lanceoleins A-G, hydroxychalcones, from the flowers ò Coreopsis lanceolata and their chemo preventive effects against human colon cancer cells. Bioorg Chem 85: 274281

15. Thompson EB, Aynilian GH, Dobberstein RH, Cordell GA, Fong HH, Farnsworth NR (1979) Biological and phytochemical investigation of plant XV, Pteryxia terebinthina var terebinthina (umbelliferae). J Nat Prod 42: 120125 